\title{
The Problem of Double Taxation for American Business Enterprises in China and a Draft Convention for Its Solution
}

\author{
KeChin Wang*
}

\section{INTRODUCTION}

$A$ BRIEF consideration of China's prewar trade with foreign counto indicate the growing urgency of a solution of the problem of taxation confronting American concerns desiring to do business there.

In prewar days, first among China's exports was wood (tung) oil, of which she is the world's major source of supply. Next come egg products, in a preserved or dried form, of which China is also the world's biggest producer. Then come bristles, carpet wools and camel's hair from the herds of Mongolia, tungsten and antimony from the Yangtze Valley, of which China has sixty per cent of the world's supply, and musk from the musk deer of Szechuan and Tibet. There are also tin from the mines of Yunnan, camphor, lacquers, vegetable oil, seeds, hand-made embroideries and laces, porcelains. ${ }^{1}$

Among China's imports, cotton goods were first on the list. There followed iron, steel and machinery, electrical equipment, aircraft and accessories, railway materials, motor cars, trucks, buses, chemicals and medicinal preparations, petroleum products, leather goods, paper, cigarettes and leaf tobacco. ${ }^{2}$

Before the first world war, American trade with China was on a small scale and could not be compared with that of other nations. In 1913, for instance, nearly thirty per cent of China's imports were accredited to Hongkong, of which the bulk was of British or European origin; over twenty per cent came from Japan; sixteen and one-half per cent was accredited to Great Britain direct; and but six per cent represented America's share. ${ }^{3}$

A.B. 1936, University of Colorado; B.C.L. 1939, M.A. 1941, Oxford University; Ph.D. 1941, University of London; Barrister-at-law 1939, Middle Temple.

${ }^{1}$ Where China Buys and Sells, U.S. Government Printing Office (1932) at 7. For China's prewar exports, see also Fong, The Postiwar Industrialization of China (1942) at 21-22.

Ibid. at 8-26.

${ }^{3}$ Ibid. at 28. 
But that war cut off China's supplies from Europe and she was forced to fall back on Japan and the United States. American firms particularly then established themselves on the China coast and revived a trade which but for the selling of kerosene and tobacco, had languished for fifty years. When the war ended, this trade was never regained by the European merchants. That in the 1929-'34 period the United States has generally predominated in western commerce with China is clearly shown in the following table."

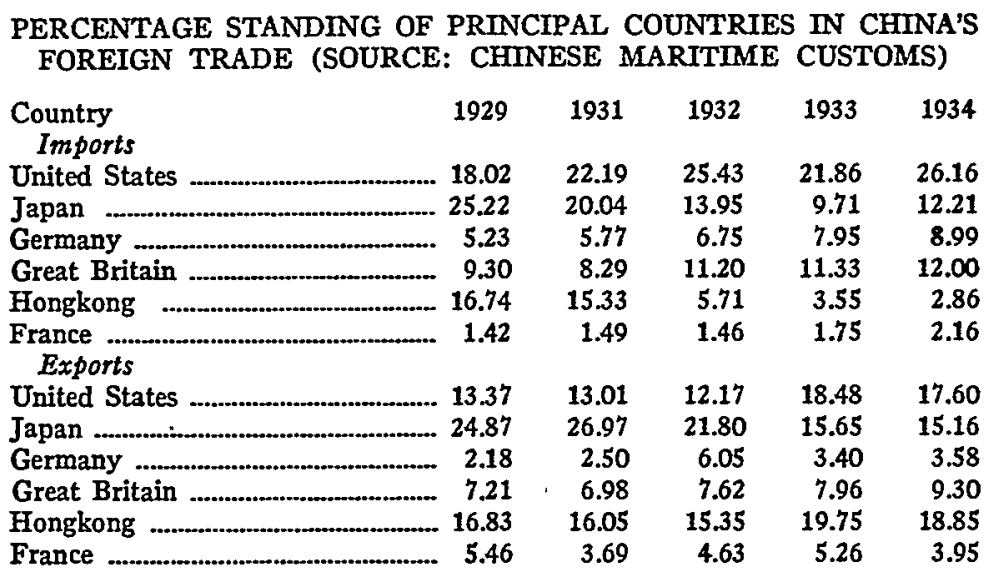

Turnimg to foreign investments, prewar capital came to China in increasing volume after the conclusion of the Opium War of 1839-42. Remer placed the total of foreign investment in China in 1902 at U.S. $\$ 787.9$ million, in 1914 at U.S. $\$ 1,610.2$ million, in 1931 at U.S. $\$ 3,242.5$ million. $^{5}$ Of this total in 1931, Great Britain and Japan each held slightly more than thirty-five per cent, the Umited States and France about six per cent each.

These investments were made chiefly in two forms. ${ }^{6}$ Direct business investments amounted to about three-fourths of the total and government obligations amounted to about one-fourth of the total. There was practically no foreign investment in Chimese private corporations. ${ }^{7}$

The American Economic Mission to the Far East placed the investments of the principal creditor countries in China at the beginning of 1935 at U.S. $\$ 1,000$ million for Great Britain, U. S. $\$ 500$ mil-

4 Ibid. at 29.

5 ReMrer, Foreign Investaients in Cenina (1933) c. V.

6 The Prospect of Foreign Investment in Chino, Contearporary CenINa, Feb. 7, 1944.

7 Ibid. 
lion for Japan, and U. S. $\$ 200$ million for the United States. According to the Mission," "The outstanding difference is the decline in the importance of Japanese investments, when Manchuria is excluded. The new investments include those of the British in railways, Japanese in cotton mills, and American in aviation."

Latest estimates place British investments in China at 6300 ,000,000 or U.S. $\$ 1,400,000,000,{ }^{0}$ American investments at U.S. $\$ 242,000,000,{ }^{10}$ and French investments at Frs.5,800,000,000 or U.S. $\$ 165,000,000 .^{11}$ These figures show that while the amount of American investments in China was far behind those of Great Britain, they do indicate a trend. That trend is the growing importance of American business interests in the China market.

The fact is that the economies of these two great countries are complementary. China is eighty per cent an agricultural country ${ }^{12}$ while the United States is highly industrialized. There is no conflict of markets and the conditions are ideal for mutual trading. Capital goods will be coming in increasing amounts from the United States to China, while agricultural products and mineral resources will be heading the other way from China to the United States. ${ }^{13}$

\section{LAWS GOVERNING AMERICAN BUSINESS ENTERPRISE IN CHINA}

In the postwar era it is estimated that China will welcome a foreign investment of U.S. $\$ 10,000,000,000$ or more, ${ }^{14}$ and there is every indication that business interests in this country will not fall behind in the general competition for markets and business investment.

Such investments may be made in four ways.

(1) Joint Capital. According to the "Regulations Governing the Utilization of Foreign Experts and Capital,"15 the government "may enter into agreements with foreign factory interests for the provision

8 Nattonal Foreign Trade Couscr, Report of the American Economic Mission to the Far East (1935) 26.

- Ch-Walden, The Sino-Japanese War and the Open Door (1938) 17 INTERNATIONAL AfFAIRS 631.

10 Dennet, Alternative American Policies in the Far East (1938) 16 FoRErGN AFFAIRS 390 .

11 Hanwell, France Takes Inventory in China (1938) 7 FAR Western SURvey 222.

12 Speech of Dr. P. W. Kuo, Chairman of Chinese Delegation to the United Nations Conference on Food and Agriculture, 1943. Reprinted, 3 Contemiporary China (1943) No. 2.

${ }^{13}$ The Promise of the Chine Market, ibid. No. 18.

14 Ibid. No. 19.

15 Promulgated 1932. Changes made in New Resolution of Sept. 11, 1943. Ibid. 
of joint capital for the operation of industries"; and Chinese private capital and foreign capital may establish joint enterprises "subject to the proviso that previous sanctions must be obtained from the Government."

According to the new Resolutions of 1943, passed by the Central Executive Committee of the Kuomintang at its Eleventh Plenary Session, "no fixed restriction shall be placed on the ratio of foreign capital in joint enterprises. ${ }^{10}$ In the organization of a joint Chineseforeign enterprise, the chairman of the board of directors shall be a Chinese, but the general manager need not necessarily be a Chinese."1\%

(2) Loan. According to the "Regulations," the government "may obtain loans from foreign interests or banking consortiums for the operation of various kinds of industry." Private enterprises may obtain loans in the same way, "subject to the proviso that previous sanctions must be obtained from the government." Further, "negotiations for foreign loans for state enterprises shall be centralized"; and that "private individuals may negotiate foreign loans for their enterprises and such loan agreements shall become effective following the approval of the Chinese Government." For an enterprise that operates under this plan, "the power of administration" shall rest with the Chinese, but the creditor "shall have the right to supervise expenditures."

(3) Temporary Concession. The "Regulations" provide that the government "may grant to foreign factory interests temporary concessions for the establishment and operation of such special kinds of industries as may call for special technical skill or contain elements of risk, provided that the said concessionaires have had long experience in operating such industries and also have ample capital at their disposal."

This type of concession will be under the general management of the concessionaire, while the government will "have the right of supervision." The term of the concession shall be fixed, machinery and equipment specified, and the condition of retrocession determined in the concessionaire agreement. Only under special circumstances will the government grant such concessions.

16 Formerly "at least $51 \%$ of the total number of shares must be held by Chinese. A majority of the members of the board of directors must be Chinese ... the chairman of the board of directors as well as the general manager must be Chinese." See Regulations Governing the Utilization of Foreign Exports and Capital (1932).

17 See supra note 14. 
(4) Alien-financed Companies Operating Under Chinese Laze. The new "Resolution' stipulates that "aliens, in accordance with Chinese laws and regulations, and having received the sanctions of the Chinese Government, may finance their own enterprises in China." And if they wish to organize a company, they must conform to the Chinese Company Law rules of 1929, which embrace four classes of companies, viz., Unlimited Liability Companies, Joint Liability Companies, Limited Liability Companies, and Joint Share Companies. ${ }^{18}$

Before the abolition of extraterritoriality, the government had no jurisdiction over foreign enterprises established in the treaty ports. There were, therefore, no separate rules regulating foreign companies, since very few of these were found beyond such ports.

There has been, however, a series of regnlations which require all companies carrying on business or trade under the jurisdiction of the national government to register with the Registration Bureau. ${ }^{10}$ But no rules are laid down as to what kind of foreign business organization will be accepted as a company and permitted to register as such.

According to provisions in the Draft Civil Code, the existence of foreign juristic persons is, as a rule, not recognized, "but this does not apply to states, administrative districts of states, commercial companies, and other juristic persons admitted by law or treaty. However, as soon as foreign juristic persons are recognized by our law, they have the same capacity to enjoy rights and the same disposing capacity as the same classes of juristic persons existing in China, except those rights expressly excluded by law or treaty and those which are barred to aliens generally."20

A Supreme Court decision held that "foreign firms established in China, no matter whether or not they are lawfully formed as juristic persons according to the laws of their nationalities, are not recognized as juristic persons, there being no express provisions contained in our existing law."21

Since the abolition of extraterritoriality, all foreign companies in China are brought under Chinese jurisdiction. There is now no room for doubt as to what the position of such a company is in China, for according to the Resolution of September 11, 1943, foreign com-

18 An English translation of the full text of the Chinese Company Law Rules is found in (1930) 4 CHINA L. Rev. 98 et seq. and following numbers.

19 See e.g., regulations issued by National Registration Bureau, Ministry of Finance, Oct. 29, 1927. Translation found in (1929) 3 Chrva L. Rev. 29 et seq. and following issue.

20 The Draft Civil Code, Art. 6; see (1928) 2 China L. Rev. 260.

21 Supreme Court Decision, Shang, 1158 Seventh year; see ibid. at 268. 
panies desiring to do business in China must conform to the Chinese Company Law rules.

\section{POSSIBLE FEES AND TAXES TO BE PAID BY AMERICAN BUSINESS ENTERPRISES IN CHINA}

The American theory of corporations is based primarily upon the strictly artificial entity of the corporation which may not migrate from the jurisdiction of its creation. ${ }^{22}$ Thus, wherever their property or business is located, and whether they do business within or without the country, ${ }^{23}$ domestic corporations are taxable regardless of the fact that they may derive all their income from sources without the United States and have no resident stockholders. ${ }^{24} \mathrm{~A}$ domestic corporation engaged in buying goods in this country is liable for income tax on the profits of the business though no tax is imposed upon foreign corporations engaged in the same business. Tax upon income derived from the business of exporting goods is not prevented by the provision that no tax or duty shall be laid on articles exported from any state, even in cases in which there is discrimination against the domestic exporter since no similar tax is exacted from foreign corporations in the same business. ${ }^{25}$

Under the federal tax structure, American corporations engaged in foreign trade or business have an election either to claim a credit or take a deduction for certain foreign taxes which they have paid. ${ }^{26}$

Such election "may be made or changed at any time prior to the expiration of the period prescribed for making a claim for credit or refund of the tax imposed by this chapter." 27 It is not the full rate of

22 Paul v. Virginia (1868) 75 U.S. 168.

23 But an exception is made in the tax treatment of certain citizens of the United States and domestic corporations who derive the bulk of their income from within a possession of the United States within the meaning of I.R.C. \$251 as amended in subsequent acts. These are taxed on the basis of the source of the income.

24 Law Opinion 1069, I-1 -C.B. (1922) 204; U.S. Treas. Reg. 45 (1920) art. 92 as amended by T.D. 3287, I-1 C.B. (1922) 116.

25 Nat'l Paper Co. v. Bowers (1924) 266 U.S. 373; Wilham E. Peck \& Co. v. Lowe (1918) 247 U.S. 165.

$26 \mathrm{~A}$ credit is usually of greater benefit to the taxpayer since the application is against tax liability; a deduction is of benefit only to the extent of the rate of tax to which the taxpayer's income subjects him.

27 I.R.C. $\$ 158$ (a) (1942). A further amendment was suggested to permit a deferred or retroactive credit where foreign income was not reported in a particular year because "blocked". This was left for coverage by departmental regulation. [See Senate Finance Comantiee Report No. 1631, 77th Cong., 2d Sess. (1942) at 50.] 
foreign taxes paid that is deductible. Under section 130 of the Internal Revenue Code for 1943, the provisions are as follows:

"b. Limit on Credit. The amount of the credit taken under this section shall be subject to each of the following limitations.

"1. The amount of the credit in respect to the tax paid or accrued to any country shall not exceed, ... in the case of a corporation the same proportion of the tax against which such credit is taken, which the taxpayer's normal-tax net income from sources within such country bears to its entire normal-tax net income for the same taxable year; and

"2. The total amount of the credit shall not exceed, ... in the case of a corporation, the same proportion of the tax against which such credit is taken, which the taxpayer's normal-tax net income from sources without the United States bears to its entire normal-tax net income for the same taxable year; and

" 3 . For the purposes of paragraphs (1) and (2) of this subsection, the terms 'normal-tax net income from sources within such country' and 'normal-tax net income from sources without the United States' shall mean the net income from such sources minus an amount equivalent to the same proportion of the credit provided in section 26(e) which the taxpayer's excess profits net income from said sources bears to its entire excess profits net income for the same taxable year."

It is not all foreign taxes, but only "income, war-profits, and excess-profits taxes," together with taxes paid "in lieu" of these that are deductible. ${ }^{28}$ In the computations, it should be noted that deductions are granted in the case of a domestic corporation for foreign taxes paid by its foreign subsidiary as well as the subsidiary of that subsidiary. ${ }^{29}$

In the case of American corporations doing business in China, special provisions are made wherein they enjoy, under the China Trade Act, certain allowances of credit $^{30}$ though they are not allowed any deductions for foreign taxes paid under this section for here they are treated as foreign corporations. ${ }^{31}$ But since the abolition of extraterritoriality in China, it is probable that such corporations will no longer enjoy special privileges but will be treated in the same way as any other business enterprise.

28 I.R.C. $\$ 131$ (a) (1938) and ibid. $\$ 151$ (b) (1942).

29 See ibid. $\$ 128(\mathrm{e})(1942)$.

${ }^{30}$ As amended by the 1939 Act, I.R.C. $\$ 208$, and the 1941 Act, I.R.C. $\$ 104$ (f). See also U.S. Treas. Reg. 103 (1940) $\$ \$ 19.262-4$ and $19.143-3$, both as amended by T.D. 4979, 1940-2 C.B. 138, 139, and T.D. 5046, 1941-1 C.B. 260, 261.

31 See I.R.C. $\$ 131$ (g) (1938). 
So much for American taxes. As for the taxes which the corporation will have to pay in China, we have these words of Counselor P. $H$. Chang, government spokesman, who said at a press conference on January 18, 1945, "(after the registration) a foreign business firm, like a Chinese one, is required to pay first, income tax; second, excess profits tax; third, stock tax; fourth, business tax. A firm that is operating at a loss naturally has to pay no income tax or excess profits $\operatorname{tax}$. A business tax (or turnover tax) is levied on the basis of the total receipts of the business and the stock tax is levied on documents stipulated by law-those are collected irrespective of profit or loss up to the present time in this country." 32

Let us now look at these taxes in further detail.

(a) Registration Fee. ${ }^{33}$ Except for insurance companies, the first fee all companies must pay, whether foreign or domestic, is the registration fee if they desire recognition as a company. ${ }^{34}$ Foreign companies in China are subject to the "Regulations for the Registration of Companies" promulgated by the Ministry of Industry on June 30 , 1931 , and amended on June 9,1943 , with respect to a revised scale of fees. It should be pointed out that no distinctions are made between foreign companies desiring to do business in China and those merely wishing to be recognized for the purposes of suit. Presumably, both classes are treated in the same way. This is obviously unfair and we should expect separate provisions to be made soon for the second class of companies. During 1943 foreign firms operating in Chungking were requested by the Chinese Government authorities to register. ${ }^{35}$

32 Text transmitted by shortwave and recorded by Chinese Consulate, Los Angeles.

33 Registration of private insurance enterprise is governed by separate provisions for on September 25, 1943, the Executive Yuan promulgated special regulations for the control of this category of concerns.

The "Insurance Enterprise Regulations" prohibit a private firm from engaging concurrently in damage and casualty insurance and life and accident insurance. Nor can insurance enterprises engage in any other form of business. The total capital of an insurance enterprise shall not be less than one million Chinese dollars, paid in cash. The amount of security deposit and ratio of reserves are to be fixed by the Ministries of Finance and Economic Affairs. Not less than $80 \%$ of the company's funds and liability reserves shall be invested within China. Local insurance associations, with the approval of the ministries concerned, are to set premium schedules and standard brokerages. Both insurance brokers and adjusters must be licensed. (ChINA TRADE NEws, April 1944).

34 Ibid. at 11.

35 The Registration of Companies. Made public June 30, 1931, promulgated July 1, 1931.

Pertinent rules on the registration of corporations follow: 
The registration fee is levied in accordance with the nature of the company and the size of its capital stock.

(i) Unlimited Liability Companies and Joint Liability Companies:

$\begin{array}{rr}\text { Capital stock of under } \$ 5,000 \text { charge } & \$ 15.00 \\ \$ 10,000 & 30.00 \\ \$ 30,000 & 45.00 \\ \$ 50,000 & 60.00 \\ \$ 100,000 & 75.00 \\ \$ 300,000 & 90.00 \\ \$ 500,000 & 120.00 \\ \$ 800,000 & 150.00 \\ \$ 1,000,000 & 180.00 \\ \$ 1,500,000 & 225.00 \\ \$ 2,000,000 & 300.00 \\ \$ 3,000,000 & 375.00 \\ \$ 4,000,000 & 450.00 \\ \$ 4,000,000 \text { for every } & \\ \text { More than } & \$ 75.00\end{array}$

Article 1. To apply for registration, a company shall submit a written application in which such particulars as are provided for under the corporation laws shall be set forth. The application, which must be signed or sealed by its directors in the case of a limited hability company, or by shareholders taking part in the management of its affairs, in the case of a company of the other classes, shall be forwarded to the Registration Office of the hsien district in which the company's head office is located.

Article 2. Upon receipt of the application, the hsien magistrate shall within five days, submit it to the Ministry of Industry (the Ministry of Economic Effairs has now taken over its work) through the Industrial Bureau of the province. After the application is duly granted by the Ministry, a permit or license sball be issued to the applicant, and at the same time an announcement to this effect shall be made in the Government Gazette.

In addition to the apphications for registration of companies, the hsien magistrate shall also submit applications filed by companies for registration of other affairs to the Ministry of Agriculture and Commerce once every month through the Industrial Bureau of the province. At the same time, the Magistrate shall file a report on such applications at the office of the Civil Governor of the province. After having submitted an application to the magistrate's yamen (office) for registration in accordance with the provisions of the Company Registration Regulations, the company shall forward a duplicate copy of its application to the Ministry of Agriculture and Commerce either directly or through the Chamber of Commerce of the locality.

In the event of a company applying for registration, aside from following the prescribed procedure of the present article, the Ministry of Agriculture and Commerce, when it deems proper, may issue the license directly to the company, if the latter's application has already been received and approved by the Ministry. [This is a translation of revised regulations governing registration of corporations May 7, 1923. Reprinted from (October 1923) ChInese Economic Monthly, and appearing in the (1922-1924) 1 Cenina L. Rev. (Nos. 1-9) 300-331.] 
(ii) Limited Liability Companies and Joint Share Companies:

$\begin{array}{cr}\text { Capital stock of under } \$ 5,000 \text { charge } & \$ 30.00 \\ \$ 10,000 & 60.00 \\ \$ 30,000 & 90.00 \\ \$ 50,000 & 120.00 \\ \$ 100,000 & 150.00 \\ \$ 300,000 & 180.00 \\ \$ 500,000 & 225.00 \\ \$ 800,000 & 300.00 \\ \$ 1,000,000 & 375.00 \\ \$ 1,500,000 & 450.00 \\ \$ 2,000,000 & 600.00 \\ \$ 3,000,000 & 750.00 \\ \$ 4,000,000 & 900.00\end{array}$

More than $\$ 4,000,000$ for every

additional million dollars add - - $\$ 150.00$

If any company desires to increase its capital, it must register and pay an additional fee subject to the same scale of calculations (see Article 11). If the company desires to establish a branch office, it must pay a fee of ten dollars (see Article 12). If the company has its main office abroad, but desires to establish a branch office in Chima, it must:

1 , pay a registration fee according to the above scale, calculated on a basis of one-half of the entire capital of the main office, or

2 , if it has a capital stock of its own, pay a registration fee calculated on the basis of its own capital stock according to the above scale.

If after such branch office has been duly registered the foreign company desires to establish further branch offices in China, it must pay an additional registration fee of ten dollars for each secondary branch office. But should such secondary branch office operate on capital stock of its own, then the registration fee will be calculated according to the above scale (Article 13).

(b) Income Tax. Incomes of profit-seeking business enterprises, including the earnings of corporations capitalized at over $\$ 2,000$, will be subject to income tax. ${ }^{36}$

The tax rates are as follows:

For incomes ${ }^{37}$ under Class A (i.e., incomes of profit-seeking business enterprises with a capital outlay of $\$ 2,000$ or over) and Class B

36 Income tax law, promulgated October 1, 1936. See Liu Fa Chuan Shu published May, 1940. Slight changes in rates are made in the new income tax law, effective February 17, 1943. See ChINA AT WAR (1943) at 66-68.

37 The tax of income is based on its source. According to the Detailed Rules for the 
(earnings of joint government and commercial enterprises) the following rates will be imposed:

(i) Tax of $3 \%$ on profits ${ }^{38}$ between $5 \%$ and $10 \%$ of the actual capital. $^{39}$

(ii) Tax of $4 \%$ on profits between $10 \%$ and $15 \%$ of actual capital.

(iii) $\mathrm{Tax}$ of $6 \%$ on profits between $15 \%$ and $20 \%$ of actual capital.

(iv) Tax of $8 \%$ on profits between $20 \%$ and $25 \%$ of actual capital.

(v) Tax of $10 \%$ on profits above $25 \%$ of actual capital. (Chapter 2, Article 3 of Income Tax Law).

For earnings of business establishments which cannot be calculated on the basis of Article 3, the following rates shall be imposed:

(i) Tax of $3 \%$ on earnings between $\$ 100$ and $\$ 1,000$.

(ii) Tax of $4 \%$ on earnings between $\$ 1,000$ and $\$ 2,500$.

(iii) Tax of $6 \%$ on earnings between $\$ 2,500$ and $\$ 5,000$.

(iv) For earnings of $\$ 5,000$ or over, $1 \%$ on each additional $\$ 1,000$. The highest rate of tax cannot be more than $20 \%$ of total earnings.

(c) Excess Profits Tax. There is an excess profits tax for the emergency period of the war promulgated by the Government on October $28,1938 .^{40}$

(i) When earnings exceed total capital by $15 \%$ to $20 \%$, tax of $10 \%$ on the excess.

(ii) When earnings exceed total capital by $20 \%$ to $30 \%$, tax of $15 \%$ on the excess.

Application of the Income Tax Law, promulgated Oct. 1, 1936, whenever the main office of a business enterprise is outside China, and a branch office is within China, or vice versa, whether or not the capital is clearly earmarked for each place of business, only that portion of the earnings traceable to sources within China will be subject to tax. (Article 5). If both its main office and branch office are situated in China, each will be taxed separately according to its individual earnings. (Article 6).

38 When calculating profits, the same rules provide that from gross income must be deducted all actual expenses paid out, defaults on payments, depreciation, public levies, amortization funds. (Ibid. Article 15.)

39 According to the same rules, by capital is meant actually paid-up capital. For those amounts intended as a sinking fund, only one-third of its total amount will be taken into account. (Ibid. Article 7.)

40 Ibid.

On February 17, 1943, the government promulgated a new wartime excess profits law. The rate has been increased from $10 \%$ to $12 \%$ on excess profits of from $20 \%$ to $25 \%$ of the capital. For excess profits over $200 \%$ of the capital, $60 \%$ is collected. See New Tax Laws Inaugurated, by shortwave from Chungking and printed in (1943) CHina AT WAR at 68-69. 
(iii) When earnings exceed total capital by $30 \%$ to $40 \%$, tax of $20 \%$ on the excess.

(iv) When earnings exceed total capital by $40 \%$ to $50 \%$, tax of $30 \%$ on the excess.

(v) When earnings exceed total capital by $50 \%$ to $60 \%$, tax of $40 \%$ on the excess.

(vi) When earnings exceed total capital by $60 \%$, tax of $50 \%$ on the excess.

Both of these taxes, income tax and excess profits tax, are collected by the income tax office under the Ministry of Finance.

(d) Turn-over Tax. ${ }^{41}$ This is a local tax on all individuals or groups operating a merchandising business there for profit. ${ }^{42}$

Each business is required to file with the provincial authorities the following particulars:

(i) The various types of goods sold, the name and location of the shops.

(ii) The name, residence and origin of owner.

(iii) The capital of the business.

(iv) The gross receipts of annual business.

(v) The net profits. (Above provisions contained in Article 3 ).

The rate of tax varies according to the regulations of each province or town, within the following limits:

(i) For estimates based on total receipts the tax is from .2\% to $1 \%$.

(ii) For estimates based on capital investment, the tax is from $.4 \%$ to $2 \%$.

(iii) For estimates based on net profit the tax is as follows:

When the net profit is not up to $15 \%$ of total capital, the tax is from $2 \%$ to under $5 \%$ of that net profit.

When the net profit is from $15 \%$ but not up to $25 \%$ of total capital, the tax is from $5 \%$ to under $7.5 \%$.

When the net profit is more than $25 \%$ of the total capital, the tax is from $7.5 \%$ to $10 \%$. (Above provisions from Article 4 ).

When the estimates for this tax are based on total receipts, there is no tax if annual receipts are not up to $\$ 1,000$. When the estimates

41 Promulgated June 13, 1931.

42 Not including those businesses with factories which have already paid a factory tax (in the latest Liu $F a$ Chuan Shu there are no provisions for a factory tax) to the central government nor those banks in the nature of limited companies who have paid income tax. The business of farming for profit is also excluded. (Article 1.) The businesses operated by the central government or the local governments are also not taxed, although joint enterprises of government and private concerns are not exempt. (Article 6.) 
are based on capital, there is no tax if the capital is not up to $\$ 500$. When the estimates are based on net profit, and when the profit is not up to $\$ 100$, there is no tax. (Above provisions from Article 5).

(e) Stamp Tax. ${ }^{43}$ This is a tax on numerous types of papers to give them validity. It is in proportion to the value that such papers represent and is roughly in the ratio of 300 to 1 . Examples of such papers are bills, receipts, storage certificates, insurance certificates, stocks and bonds, marriage licenses, amusement tickets, passports.

(f) Tax on Onenership of Land. ${ }^{44}$ It should first be pointed out that the following types of land are not available to aliens (presumably this includes alien companies) : ${ }^{45}$

Agricultural land.

Forests.

Pastoral land.

Fishing areas.

Salt deposits.

Mineral deposits.

Strategic locations, defense areas, border regions.

For purposes of tax, land is divided into the following classes: ${ }^{45 \mathrm{a}}$
A. Improved land within city limits.
B. Unimproved land within city limits.
C. Wasteland within city limits.
D. Improved land beyond city limits.
E. Unimproved land beyond city limits.
F. Wasteland beyond city limits.

In each case the tax, although a central government tax, will be determined by the local taxing officials within the following limits:

1. For type A 1 per cent to 2 per cent of the estimated land value.

2. For type $B 1.5$ per cent to 3 per cent of the estimated land value.

3. For type $C 3$ per cent to 10 per cent of the estimated land value.

4. For type $D$ up to 1 per cent of the estimated land value.

5. For type $E 1.2$ per cent to 1.5 per cent of the estimated land value.

6. For type F 1.5 per cent to 10 per cent of the estimated land value.

43 Promulgated Sept. 1, 1935.

44 Promulgated Jan. 12, 1914.

45 Article 17.

45a Improved land is further divided into two classes: 1 , where there are building improvements, 2, where there are farming improvements. Whether or not there are any improvements made on the land, and to what extent, is determined by experts appointed by the local government, Art. 237, Chapter II. Ibid. Before any such farming improvements will be taken into consideration, they must have sufficiently improved the value of the land from $10 \%$ to $50 \%$, and in the case of building improvements, at least $20 \%$. 
The land tax is a local tax, but may be appropriated by the Central Government for the purposes of improving or repairing the land. The total amount cannot, however, exceed ten per cent of the tax collected. ${ }^{48}$

(g) The Property Tax Law. ${ }^{47}$ The scope of tax includes any transaction regarding the lease or sale of land, houses, warehouses, wharves, forests, mining establishments, boats, vehicles and machinery. Property of government offices, cultural, educational and public welfare enterprises, are exempt from taxation; so are dealings bringing in income less than $\$ 3,000$ for lease of property, $\$ 5,000$ for sale of property, and $\$ 10,000$ for sale of farms for agricultural purposes.

The term "income" in the tax refers to the amount of profit earned through lease or sale of property. If the property is leased on a longterm basis or for a period exceeding fifteen years, it is considered as sold.

Rates on the lease of property begin with ten per cent for the smallest amount of profit until the maximum of eighty per cent is reached. Rates on the sale of property begin with ten per cent for any amount of profit exceeding $\$ 5,000$. Similar increases in the rates are made until fifty per cent is collected on profit exceeding $\$ 2,000,000$.

\section{A PROPOSED DRAFT CONVENTION BETWEEN CHINA AND THE UNITED STATES FOR THE PREVENTION OF DOUBLE TAXATION IN THE CASE OF BUSINESS ENTERPRISES DOING BUSINESS IN EITHER COUNTRY}

We have now completed our cursory examination of China's prewar trade with other countries and we have seen the tendency for increased trading with the United States. In the new regulations we have seen that foreigu businesses with interests in China are called upon to pay a variety of taxes which in some instances may tend to discourage that free flow of commerce so essential to her future reconstruction and development as a great stabilizing factor in the Far East. Bearing these possibilities in mind, we shall conclude this paper by presenting a draft convention between China and the United States, to the end that the heavier burden arising from double taxation may be largely eliminated for the benefit of the businessmen of both countries.

In the provisions of the draft the reader will see that special effort

46 Chapter IV, Art. 233.

47 Effective Jan. 29, 1943. See New Tax Laws Inaugurated, by shortwave radio for Chungking, in (April, 1943) Crina AT WAR. 
has been made to encourage American firms to do business in China. We hope that this incentive, in terms of lighter taxes, will help to attract would-be investors to a country whose economy is complementary to America's, and where increased trading will bring the greatest benefits to both nations.

The draft convention follows: 48

Being desirous to prevent the double taxation of the income of business enterprises, the High Contracting Parties have agreed to the following provisions:

ARTICLE I. The taxes referred to in this Convention are:

(a) In the case of the United States of America:

(1) The Federal income tax, including surtaxes and excess profits taxes.

(2) The Federal capital stock tax.

(3) The declared value excess-profits tax.

(b) In the case of the Republic of China:

(1) The income tax, including excess profits tax.

(2) The turnover tax.

(3) The registration fee.

It is mutually agreed that the present Convention shall also apply to any other or additional taxes imposed by either contracting state, subsequent to the date of the signature of this Convention, upon substantially the same basis as the taxes enumerated therein.

The benefits of this Convention shall accrue only to citizens of the United States of America, to citizens of China, and to corporations and other entities registered in either country.

ArTICLE II. 1. As used in this Convention, "fiscal domicile" in the case of an individual means the place where he has his normal residence, residence being understood to mean a permanent home. When he has a fiscal domicile in both contracting states, the tax is im-

48 In this Draft Convention, the widest basis for an agreement is selected so that the two parties may select and choose how much they wish to include in any actual treaty. The Draft Convention is modelled after that of the Convention and Protocol between the United States of America and Sweden, 1929, Treaty SerIes 958.

The Chinese turnover tax may be compared with the American capital stock tax, since neither is measured by the amount of actual income, but is based on the assets of the business.

The Chinese land tax and property tax have no equivalent in Federal tax laws. They do correspond to the state property taxes, but since the Federal government has no jurisdiction over the fiscal policy of the states, these, as well as the state excise taxes and state income taxes must be left out from the terms of this Convention.

This Convention is drafted without reference to the China Trade Act, which, no doubt, will be revised or abolished after the war just as it is suspended during the war. 
posed by that state in which the taxpayer has stayed for the longest time durmg the fiscal year. When that period cannot be determined, or when it is not certain where his fiscal domicile is under the above definition, the decisive test shall be nationality.$^{40}$ "Fiscal domicile" in the case of corporations means the place where its center of management or control is located, or, if this cannot be determined, or, if there are more than one such center, then the state of incorporation..$^{50}$

2. "Permanent establishment" mcludes branches, mines and oil wells, plantations, factories, workshops, warehouses, offices, agencies, installations, and other fixed places of busmess of an enterprise but does not include the casual or temporary use of merely storage facilities. A permanent establishment of a subsidiary corporation shall not be deemed to be a permanent establishment of the parent corporation. When an enterprise organized under the laws of one of the contracting states carries on business in the other state through an employee or agent, established there, who has general authority to contract for his employer or primcipal, such enterprise shall be deemed to have a permanent establishment in the latter state. But the fact that an enterprise of one of the contracting states has business dealings in the other state through a bona fide commission agent, broker, or custodian shall not be held to inean that such an enterprise has a permanent establishment in the latter state.

3. When doubt arises with respect to residence or with respect to the taxable status of corporations or other entities, the competent authorities of the two contracting states may settle the question by mutual agreement.

ARTICLE III. An enterprise with its fiscal donnicile in one of the contracting states is not subject to taxation by the other contracting state in respect of its industrial or commercial profits except in respect of such profits as are allocable to its permanent establishment in the latter state.

No account shall be taken in determining the tax in one of the contracting states, of the mere purchase of merchandise effected therein by an enterprise of the other state..$^{51}$

40 We are here following the suggestion of the Austrian government submitted to the League of Nations in 1928, Document C 495 M 1451928 II. In most other conventions, the method used is to apportion the tax according to the length of stay in each state during the fiscal year, but we beheve the accounting may become too complicated.

50 Since a corporation can be organized in most any state, a better test seems to be the state where its "brains" are located.

61 According to United States law, it has never taxed those foreign corporations 
If an enterprise has one or more permanent establishments, there shall be attributed to each of such permanent establishments the net business income which it might be expected to derive if it were an independent enterprise engaged in the same or similar activities under the same or similar conditions. Such net income will, in principle, be determined on the basis of the separate accounts pertaining to such establishment.

The fiscal authorities of the contracting states shall, when necessary, in the execution of the preceding paragraph, rectify the accounts produced, notably to correct errors or omissions, or to re-establish the prices or remunerations entered in the books at the value which would prevail between independent persons dealing at arm's length.

If an establishment does not keep an accounting showing its own operations, or if such accounting does not correspond to the normal usages of the trade in the country where the establishment is situated, or if the rectifications provided for in the preceding paragraph cannot be effected, the fiscal authorities may determine empirically the business income by applying a percentage to the turnover of that establishment. This percentage shall be fixed in accordance with the nature of the transactions in which the establishment is engaged and by comparison with the results obtained by similar enterprises operating in the country.

If the methods of determination provided for in the preceding paragraphs are found to be inapplicable, the net business income of the permanent establishment may be determined by a computation based on the total income derived by the enterprise from the activities in which such establishment has participated. This determination shall be made by applying to the total income coefficients based on a comparison of the value of sales, number of hours worked, total capital involved in the business in each country, total stocks of goods maintained in each country, total salaries and established expenses, total credits arising in each country, and where tangible property or real estate is involved, the total value in each country. Such value may be modified, where it is not appropriate, by total area, cubic space or other criteria for productive output. ${ }^{52}$

ARTICLE IV. When an enterprise of one of the contracting states,

simply because they bave made purchases in this country. This is a reasonable rule and is berein followed.

52 See report of the Four Professors to the Fiscal Committec of the League of Nations, 1923. League of Nations Document EFS 73 F 19. 
by reason of its participation in the management or capital of an enterprise of the other contracting state, makes or imposes on the latter in their commercial or financial relations conditions different from those which would be made with an independent enterprise, any profits which should normally have appeared in the balance sheet of the latter enterprise, but which have been in this manner diverted to the former enterprise may, subject to applicable measures of appeal to the appropriate authorities, be incorporated in the taxable profits of the latter enterprise. In such case consequent rectification may be made in the accounts of the former enterprise. ${ }^{53}$

ARTICLE V. Income which an enterprise of one of the contracting states derives from the operation of ships registered in that country shall be taxable only in the state in which registered. Income derived from the operation of aircraft shall be subject to the provisions of Article III. ${ }^{54}$

ARTICLE VI. Income of whatever nature derived from real property, including gains derived from the sale of such property, as well as interest derived from mortgages or bonds secured by real property, shall be taxable only in the contracting state in which the real property is situated. 55

ARTICLE VII. Royalties and rents from real property or in respect of the operation of mines, quarries, or other natural resources shall be taxable only in the contracting state in which such property, mines, quarries, or other natural resources, are situated. ${ }^{56}$

63 This provision is necessary to ensure that subsidiary corporations and their parent are dealing at arm's length.

54 In the case of ships, we are following precedent. In any case, coastal shipping will be generally restricted to the ships registered in the country. But in the case of aircraft, we see possibilities of amazing development and expansion after the war. Owing to China's undeveloped aircraft industry, most of the air travel and air transport over China itself will be directly or indirectly dominated by foreign enterprise. It would seem unfair that such enterprises gathering in the profit from Chinese sources should be free from tax. Their incoune can be taxed according to the rules of apportionment given in Article 11 , and the proportionate share can be further determined by the number and size of hangars inside the country of origin, the repair shops, the ofices, the number of workers and other personnel, and the number of air miles between points in the country of origin for internal traffic and between points in the country of origin and the country of residence for international traffic.

55 In the case of immovables, tax should follow situs. There are no sufficient reasons why an exception should be made in the case of interest from mortgages or bonds secured by real property.

56 The right of ownership in these natural resources has certain limitations in Chima. For instance, the operation and development of basic resources will be in the hands of 
Other royalties and amounts derived from within one of the contracting states by a resident or by a corporation or other entity organized under the laws of the other contracting state as compensation for the right to use copyrights, patents, secret processes and formulas, trade-marks and other analogous rights, shall be exempt from taxation in the former state. ${ }^{57}$

-ARTICLE VIII. 1. Dividends shall be taxable only in the contracting state in which the profits out of which such dividends have been paid are made. These will generally be taxable in the state where the permanent establishment is located and from whose activities the profits are derived. ${ }^{58}$

ARTICLE IX. Interest on bonds, notes, or loans shall be taxable only in the contracting state within whose territory the activity productive of such interest is carried on..$^{69}$

Article X. Gains derived in one of the contracting states from the sale or exchange of capital assets by a national or individual resident or a corporation or other entity organized under the laws of the other contracting state shall be exempt from taxation in the former state, provided such national or individual resident or corporation or other entity has no permanent establishment in the former state.

ARTICLE XI. Wages, salaries and other forms of compensation and pensions paid by one of the contracting states or by the political subdivisions or territories or possessions thereof to individuals residing in the other state shall be exempt from taxation in the latter state.

Private pensions and life annuities derived from within one of the contracting states and paid to individuals residing in the other contracting state shall be exempt from taxation in the former state.

ARTICLE XII. (a) Compensation for labor or other personal services, including the practice of the liberal professions, shall be taxable only in the contracting state in which such services are rendered.

the government or in joint private and government interests. See Sun Fo, China's Postwar Economic Policy (Dec. 25, 1944) Contemrorary China.

5i In China, laws on trademarks, patents and copyrights have been formulated but are in the process of revision.

58 The principle of "origin" is followed here. Reference is also made to the suggestion of the Union of South Africa Government to the Fiscal Committee of the League of Nations, Document C 495 M 147, 1928 Ir.

59 Since Chinese interests abroad will be incommensurate with the foreign interests which will be established in China, adherence to the "residence" principle offers no real reciprocity for Chinese nationals. Foreign investors will note that the Chinese rates are comparatively low, so they would probably prefer to pay the Chinese tax rather than the American tax on the same amounts of income. 
(b) The provisions of this Article shall have no application to the income referred to in Article X.

ARTICLE XIII. Students or business apprentices and engineering apprentices of one contracting state residing in the other contracting state exclusively for purposes of study or for acquiring practical experience shall not be taxable by the latter state in respect of remittances received by them from within the former state for the purposes of their maintenance or studies.

ARTICLE XIV. It is agreed that double taxation shall be avoided in the following manner:

(a) Notwithstanding any other provision of this Convention, the United States of America in determining the income and excess-profits taxes, including all surtaxes, of American citizens or corporations registered in America, may mclude, on the basis upon which such taxes are imposed, all items of income taxable under the revenue laws of the United States of America. The United States of America shall, however, deduct the amount of the taxes specified in Article I(b) (1) and (2) of this Convention or other like taxes from the income tax liability which the taxpayer's net imcome taxable in China bears to his entire net income. ${ }^{60}$

(b) Notwithstanding any other provisions of this Convention, China, in determining the graduated tax on income and property of Chinese nationals or corporations or other entities registered in China, may include on the basis upon which such tax is imposed all items of income and property subject to such tax under the taxation laws of China. China, however, shall deduct from the tax so calculated that portion of such tax liability which the taxpayer's income and property exempt from taxation in China under the provisions of this Convention bears to his entire income and property.

ARTICLE XV. In the application of the provisions of this Convention the benefits of Section 131 of the United States Revenue Act of 1938, relating to credits.for foreign taxes, shall be accorded, but the credit provided for in Article XIII(a) of this Convention shall not extend to United States excess-profits taxes nor to the surtax imposed on personal holding companies.

ARTICLE XVI. Citizens of each of the contracting states residing

60 In principle, the Chinese turnover tax is equivalent to the American capital stock tax, both being measured irrespective of losses and gains of the business. Hence, the sum paid in China on the Chinese income tax and turnover tax are deducted from the American taxes on income and capital stock. 
within the other contracting state shall not be subjected in the latter state to other or higher taxes than are imposed upon the citizens of such other state.

ARTICLE XVII. The provisions of this Convention shall not be construed to deny or affect in any manner the right of diplomatic and consular officers to other or additional exemptions now enjoyed or which may hereafter be granted to such officers, nor to deny to either of the contracting states the right to subject to taxation its own diplomatic and consular officers.

ARTICLE XVIII. With a view to the more effective imposition of the taxes to which the present Convention relates, each of the contracting states undertakes to furnish to the other contracting state pertinent information which its competent authorities have at their disposal or are in a position to obtain under its revenue laws insofar as such information may be of use to the authorities of the other contracting state in the assessment of the taxes to which this Convention relates. ${ }^{\text {I1 }}$

61 See Article XIX, TaX Convention Witra Canada, Signed March 4, 1942. 56 Stat. (1942) 1405. 